\title{
Participatory 3D modelling as a socially engaging and user-useful approach in ecosystem service assessments among marginalized communities
}

\author{
Sara O.I. Ramirez-Gomez ${ }^{\text {a, b, * }}$, Pita Verweij ${ }^{\text {b }}$, Lisa Best ${ }^{a}$, Rudi van Kanten ${ }^{\text {a }}$, \\ Giacomo Rambaldi ${ }^{\mathrm{c}}$, Roderick Zagt ${ }^{\mathrm{d}}$ \\ a Tropenbos International Suriname, Prof. Dr. Ruinardlaan (CELOS Building), Paramaribo, Suriname \\ ${ }^{\mathrm{b}}$ Copernicus Institute of Sustainable Development, Faculty of Geosciences, University of Utrecht, 3584 CS Utrecht, The Netherlands \\ ${ }^{c}$ Technical Centre for Agricultural and Rural Cooperation, 6708 PW Wageningen, The Netherlands \\ d Tropenbos International, 6700 AE Wageningen, The Netherlands
}

\section{A R T I C L E I N F O}

\section{Article history:}

Received 9 July 2016

Received in revised form

12 January 2017

Accepted 1 March 2017

Available online 7 April 2017

\section{Keywords:}

Ecosystem services

Disempowerment

Distrust

Local livelihoods

Logging

Participatory 3D modelling

\begin{abstract}
A B S T R A C T
Land use decision making in the Upper Suriname River area knows a history of disempowerment and marginalization of the Saamaka communities inhabiting the area. Non-recognition of land rights is at the origin of this problem. This is aggravated by the increasing over-exploitation of timber resources by powerful stakeholders and the unfair distribution of timber benefits. This has left Saamakans marginalized, causing distrust and opposition among themselves and towards outsiders. Furthermore, as a result of deforestation, Saamakans face detrimental changes in the ecosystem services (ES) that support their traditional livelihoods, with important effects for their wellbeing. This environment of distrust, opposition and marginalization makes it difficult to assess these concerns. Hence, an ES assessment approach that would generate salient ES knowledge while generating trust, communication among stakeholders and local capacity building was needed. In this paper we evaluate whether Participatory 3D modelling (P3DM) is an effective approach for ecosystem services assessments in such disenabling environments. We evaluate this by using empirical data from an ES assessment in the Saamaka region using a P3DM approach. Results show the efficient identification and evaluation of 36 ES representing provisioning, cultural and regulating service categories with crops, fish, wild meat, timber and forest medicines identified as most important. We found a decrease in the demand and supply of crops, fish and wild meat associated with ecosystem degradation, out-migration and changes in lifestyles. Further, our findings show an increasing demand and decreasing supply for timber related to over-exploitation. We provide evidence of the utility of P3DM to foster multi-functional landscape development among wary communities. Further, we discuss the usefulness of the approach and the necessary conditions needed for P3DM process to tackle the needs of the local communities as well as the need for a broader P3DM implementation strategy beyond the engagement, screening, and diagnostic phases of ES assessments when the aim is to enhance ES outcomes for marginalized communities.
\end{abstract}

๑) 2017 Elsevier Ltd. All rights reserved.

\section{Introduction}

More than 50 million people live in remote regions and depend entirely on functioning forest landscapes for the provision of food,

\footnotetext{
* Corresponding author. Copernicus Institute of Sustainable Development, Faculty of Geosciences, University of Utrecht, 3584 CS Utrecht, The Netherlands.

E-mail addresses: s.o.i.ramirez-gomez@uu.nl, soi.sararamirez@gmail.com (S.O.I. Ramirez-Gomez).
}

medicines and shelter (Newton, Miller, Byenkya, \& Agrawal, 2016; Sunderlin et al., 2008). Infrastructure investments such as roads and dams, as well as extractive industries like gold mining and logging, are changing forest landscapes in profound and uncertain ways (Lambin \& Meyfroidt, 2010). These activities have differential impacts on localities and communities across regions in the form of changing consumption patterns, transformation of traditional land use practices, among others (Nelson et al., 2006). In some cases, they trigger forced migration and consequently marginalization 
and disempowerment (Terminski, 2014). Indigenous communities living in remote and poorly governed regions tend to bear the brunt of the negative effects of these developments while benefiting little of the prosperity they generate (O'Faircheallaigh, 2013). They are vulnerable because their livelihood means rely on the ecosystem services that are susceptible to the impacts of these economic activities (Willemen, Drakou, Dunbar, Mayaux, \& Egoh, 2013).

In some cases, top-down, expert driven land use decision making has left rural communities feeling marginalized and disempowered, leading to distrust and opposition towards outsiders (Ban et al., 2013; Kumar \& Kumar, 2008). Distrust has been recognized as an important obstacle to effective natural resource management (Hahn, Olsson, Folke, \& Johansson, 2006). Hence researchers and practitioners identify trust as essential to effective natural resource management and implementation (Fazey et al., 2013; Reed, 2008; Stern \& Baird, 2015). Despite the increasing research efforts, information on how to generate salient, credible and legitimate knowledge (for a definition see Cash et al., 2003) for the integrated management of natural resources among wary communities in remote regions, promoting empowerment and enabling local ownership and trust, remain key challenging issues (Chaffin, Gosnell, \& Cosens, 2014; McCall, 2003; Olsson et al., 2006).

By the same token, several scholars have pointed out the gaps towards a science-policy-practice interface in ways that enhance ecosystem services (ES) outcomes for marginalized communities: 1) Turning science and technology into action in a manner that enhances a collaboration of local stakeholders in the co-production of ES information while creating capacity among local communities so that they can better participate in decision making (Cash et al., 2003; Fischer et al., 2015; Miller et al., 2014); 2) Attaining a fair distribution of the benefits from ES (Bennett et al., 2015; Daw, Brown, Rosendo, \& Pomeroy, 2011; Pascual et al., 2014) (e.g. access to provisioning services such as food, water, fertile soil, timber); 3) Identifying alternative livelihood sources for the rural poor that avoid compromising environmental sustainability (Dawson, Rounsevell, Kluvánková-Oravská, Chobotová, \& Stirling, 2010; Poppy, Jepson, Pickett, \& Birkett, 2014; Sayer et al., 2013) (e.g. alternatives to the involvement of poor rural communities in illegal timber and mining activities in order to make a living); and 4) Procuring appropriate communication channels between experts, local people and policy makers, in a language that is understood by all in order to deal with conflicts between actors, increase transparency, bring all perspectives into the negotiation table and establish criteria for decision making (Bennett et al., 2015; GarcíaNieto et al., 2015; Palomo, Felipe-Lucia, Bennett, Martín-López, \& Pascual, 2016; de Groot, Alkemade, Braat, Hein, \& Willemen, 2010).

It is only through the engagement of the end users of the knowledge generated by research that science on ES can pursue transformative interventions and render an important contribution towards a fair and more equitable sustainable development (Fischer et al., 2015; Reyers, Nel, O'Farrell, Sitas, \& Nel, 2015; Sitas, Prozesky, Esler, \& Reyers, 2014). This implies that, in marginalized regions, ES assessments should apply user friendly methods that can be understood by all (Fischer et al., 2015; Ostrom, 2009). A more friendly and inclusive ES assessment approach might enhance the quality and likelihood of durability of ES management interventions (Bohensky \& Maru, 2011; McLain et al., 2013; Ostrom, 2007, 2009).

Participatory Geographic Information Systems (PGIS) comprise an array of methods based on place-based mapping by local communities, seeking to democratize spatial information and technology (Brown \& Fagerholm, 2014). PGIS have been proposed as an important tool to strengthen the capacity of the end users to engage and participate effectively in decision making by legitimizing local peoples knowledge, by enabling ownership and by preparing local stakeholders to judge and respond to changing environmental conditions (Jankowski, 2009; McCall \& Minang, 2005; Rambaldi, Kwaku Kyem, McCall, \& Weiner, 2006; Sayer et al., 2013; Talen, 2000). Refutably, compared to conventional GIS, PGIS may lack cartographic precision (McCall, 2006), yet PGIS can be a powerful method to produce social outcomes (i.e. social learning and social capital) (Brown \& Fagerholm, 2014) which “... are arguably equally important objectives in the achievement of sustainable future land use" (Brown \& Kyttä, 2014, p. 13).

In this article we use a PGIS tool centered on a community-based process which integrates local knowledge on ES with data on elevation of the land to produce physical 3D models known as Participatory 3D Modelling (P3DM) (Rambaldi \& Callosa-Tarr, 2001). We adopted P3DM as the means to engage with local stakeholders in a collaborative, spatially-explicit research on ecosystem services, with a view to contribute to informed and participatory decision making in the Upper Suriname River area where people, belonging to the Saamaka tribe, have lived for centuries. By using P3DM we wanted to research the social engagement and user-usefulness of the P3DM approach in collaborative ecosystem service assessment in a remote forest landscape undergoing land use pressures, in order to enhance ES outcomes for marginalized local communities that show distrust and opposition towards outsiders. We answered this question based on empirical findings that specifically: 1) identified and mapped ecosystem services that Saamaka people value most for their contribution to local livelihoods, 2) ranked ES that are more important for their income and subsistence, 3 ) explored local perceptions of change in the supply and demand of those prioritized services, 4) assessed the opinion of local and external stakeholders regarding the usefulness of the P3DM in the context of the study area and 5) gauged the main concerns of local community regarding the flow of important ES.

The socio-economic and cultural context of the Saamaka territory pose the need for a more user-friendly and socially engaging approach (Cowling, 2014; Cowling et al., 2008). The Saamaka people have a history of marginalization and disempowerment, both during the colonial period as well as after the independence of the country in 1975 and for this reason they have been wary towards outsiders. Some of the major causes of community disempowerment in the context of this study include:

- The building of the Brokopondo reservoir in 1960's to supply the demands of the bauxite industry and the city capital: Over 300,000 ha of Saamaka territory was flooded causing the transmigration of more than 4000 villagers which triggered the loss of burial grounds, sacred places and agricultural fields (Price, 2012a). Paradoxically, until today, 62 villages (approximately 17,000 people), including those that were transmigrated lack access to electricity.

- Absence of de jure land rights: Although de facto rights exist (Schlager \& Ostrom, 1992), traditional land right are not legally recognized by the national law and therefore Saamaka communities lack both tenure security and secure access to livelihood resources.

- Lack of consultation and participation: Logging activities that have taken place in the Saamaka territory, damaging agriculture fields and other important places, without proper consultations nor implementation of free prior informed consent (InterAmerican Court of Human Rights, 2007; Price, 2012b).

We used the typology for the classification of ecosystem services of Vallés-Planells, Galiana, and Van Eetvelde (2014) because in our study context it provided more flexibility to include a broader range of functions valued in economic, socio-cultural and ecological sense 
(Termorshuizen \& Opdam, 2009) as well as the consideration of the carrier function for basic every day human activities referred in de Groot (2006). This is the consideration of spaces for daily activities such residential space, communication paths, places to work as provisioning services of the landscape. This study made part of the diagnostic phase of the broader ongoing program Towards Productive Management of Transformed Forest Landscapes of Tropenbos International Suriname in the hinterland of Suriname.

\section{Study area}

The Upper Suriname River Basin (USRB) is located south from the Brokopondo reservoir between the $56^{\circ} \mathrm{W}$ and $54^{\circ} \mathrm{W}$ longitude and $4^{\circ} \mathrm{N}$ and $3^{\circ} \mathrm{N}$ latitude (Fig. 1), approximately $315 \mathrm{~km}$ south of Paramaribo. There is a paved road to Atjoni, the landing place, from where outboard motor boats are taken to reach to the villages upstreams. The area is covered with 124,989 ha of primary forests and a fringe of 75,906 ha of secondary forests along the Suriname River created as the result of shifting cultivation. The average annual rainfall is $2700 \mathrm{~mm}$ (Nurmohamed, Naipal, \& Becker, 2008). The region is inhabited by Afro-Surinamese people belonging to the
Saamaka tribe. Their livelihoods have been traditionally based on shifting cultivation, fishing, hunting and harvesting of timber and non-timber forest products, mainly for subsistence. Since the construction and paving of the Atjoni road in 2010, the people have been increasingly involved in economic activities such as trade in non-timber forests products, craft making, boat transport, and ecotourism. The total population in the entire USRB is 17,954 people according to the latest census (Algemeen Bureau voor de Statistiek in Suriname, 2010). Inhabitants are distributed in 62 villages along the Suriname River.

In our study, we focus on 24 villages located in the northern part of the USRB. These were divided in two groups of 14 and 10 villages which we labeled as sub-region 1 and sub-region 2 respectively (Fig. 1). Such division was suggested by local traditional authorities who explained that although they all belong to the same tribe and have similar culture and land use traditions, yet there are some differences between these two groups. For example, nine of the 14 villages in sub-region 1 are of transmigrated origin due to the construction of the Brokopondo reservoir whereas in sub-region 2 there is only one transmigration village. Additionally, sub-region 1 is influenced by roads and commercial logging while sub-region 2

\section{South America}
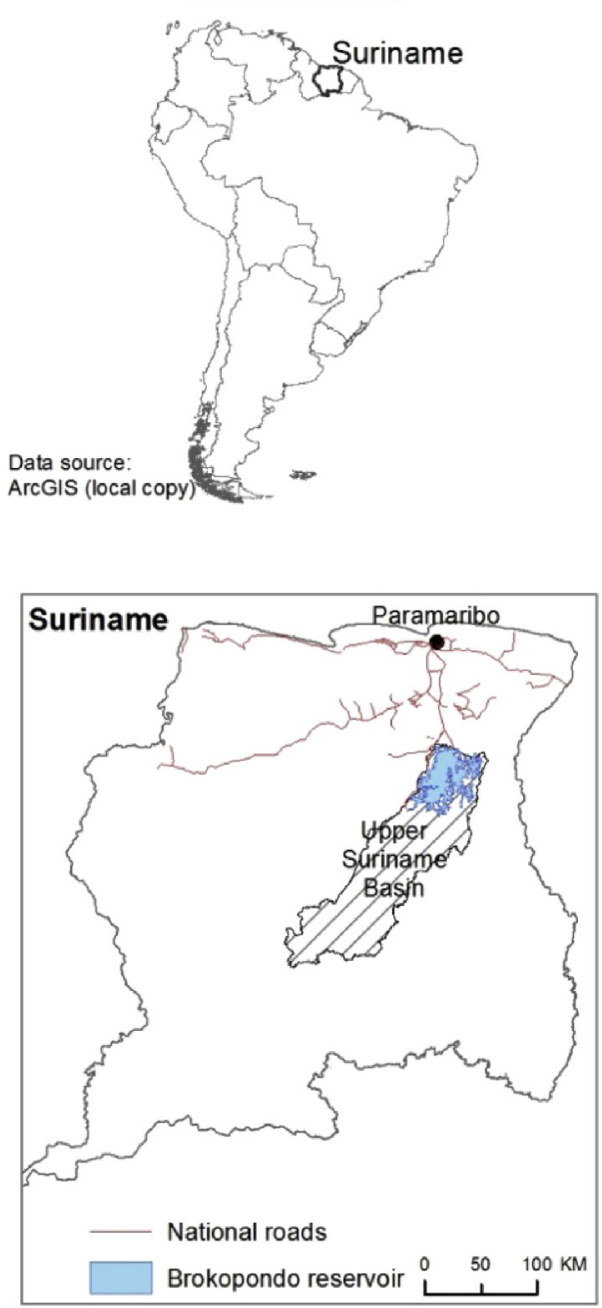

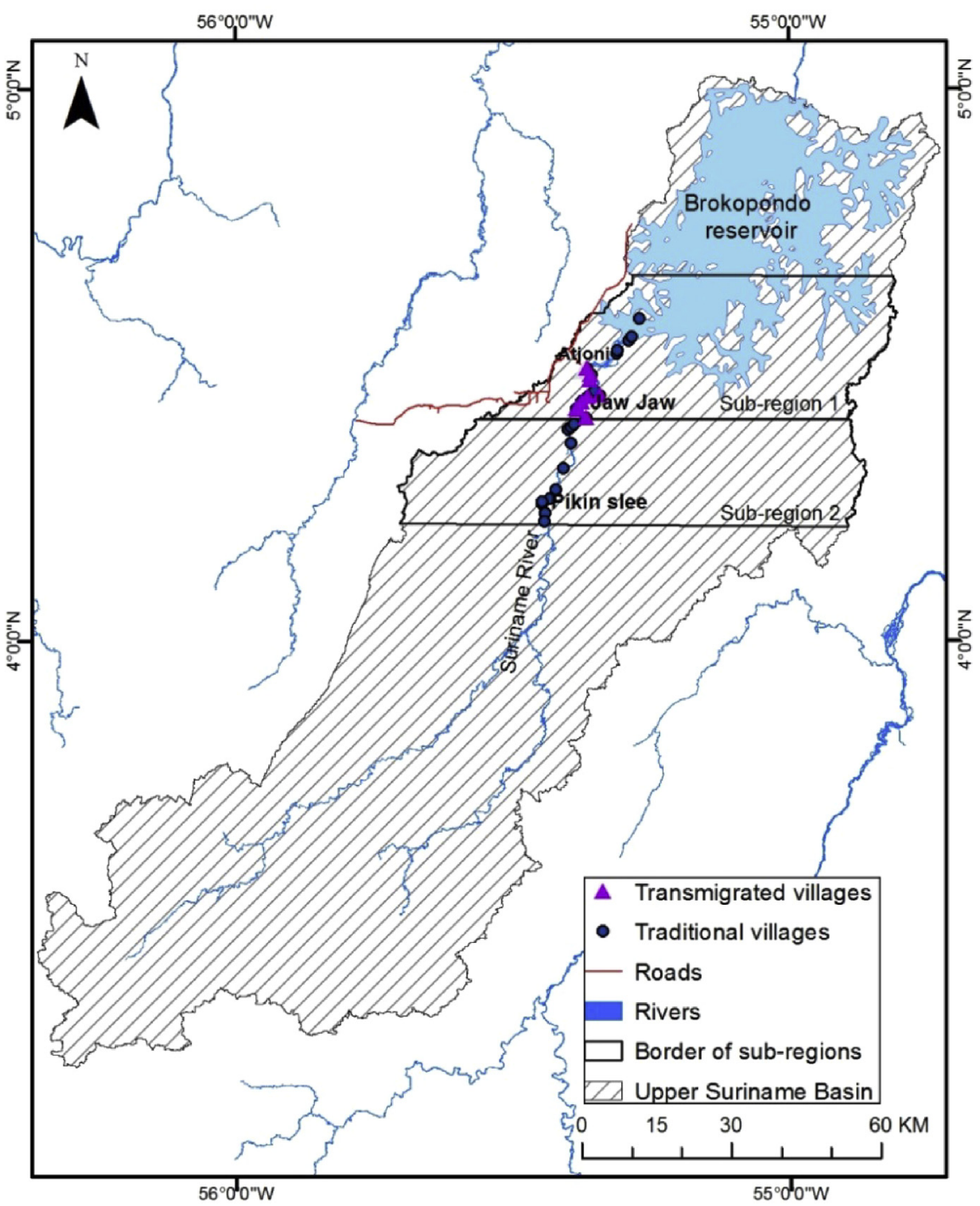

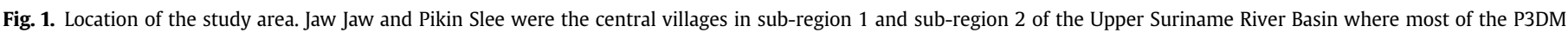
activities took place. 
is still remote and no commercial logging activities have yet taken place. Additionally, the local traditional authorities explained that such division is the same as applied in projects with external organizations. Regarding population size, there are 3986 and 6134 inhabitants in sub-region 1 and 2 respectively. None of the 24 communities in the two sub-regions hold legally recognized land titles.

\subsection{The stakeholders in the study area}

We identified in the Upper Suriname River area two stakeholders' groups namely internal and external stakeholders. Local stakeholders are those members of the Saamaka community living inside the area and who can be directly affected by land use management decisions or actions. External stakeholders are defined as those who can influence decisions that affect those internal stakeholders. Within the context of this study, the most relevant external stakeholders are the Ministry of Regional Development and the Forest Service who are in charge of forest management. Similarly, the Ministry of Public Works in charge of infrastructure investments as well as extractive industries such as the State Oil Company of Suriname and the mining industry. Other include the University of Suriname, civil society organizations and NGO's in Suriname whose work is to observe and produce information for sound decision making.

\section{Methods}

This study integrates an array of participatory methods commonly used to gather reliable landscape information that is relevant to marginalized communities living in remote tropical regions (Chambers, 2007; Lynam, De Jong, Sheil, Kusumanto, \& Evans, 2007; Villamor, Palomo, Santiago, Oteros-Rozas, \& Hill, 2014). Data were collected from multiple sources such as participatory mapping, focus groups discussions (FGDs), workshops, semi-structured interviews, in situ conversations, participant observations, notes from the field and sound recordings. The summary of the methods used and the aim are summarized in Table 1. Participants from the study area were selected on a volunteer basis (Goodchild \& Li, 2012). Both men and women were informed about the activities and were free to participate.

Before the implementation of project activities, an informed consent procedure was followed (Schreckenberg et al., 2014). First a general consultation meeting was organized to inform local communities about the project aims and to ask for their oral consent. Subsequently, before every workshop or interview, written informed consent was asked from each participant. A separate consultation meeting was held with traditional local authorities to define and agree on the extent of the study area. Creating trust and interest in collaboration on behalf of potential participants was crucial for the engagement process because of the many doubts about data usability, benefit sharing and tangible outputs among these communities.

\subsection{Identification of important landscape features}

We implemented a total of six workshops (three in each subregion) to gather the list of landscape features. In order to get meaningful interaction and greater in depth discussions, participants were divided into focus groups of four to five people, men

Table 1

Summary of the methods implemented to gather landscape and ES information during the P3DM process.

\begin{tabular}{|c|c|c|c|c|c|c|c|}
\hline \multirow[t]{2}{*}{ Activity } & \multirow[t]{2}{*}{ Aim } & \multirow[t]{2}{*}{$\begin{array}{l}\text { No. of } \\
\text { activities }\end{array}$} & \multirow[t]{2}{*}{ Who was involved? } & \multicolumn{2}{|c|}{$\begin{array}{l}\text { No. of } \\
\text { participants }\end{array}$} & \multirow[t]{2}{*}{ Methods } & \multirow[t]{2}{*}{ Date } \\
\hline & & & & Female & Men & & \\
\hline Inception meeting & $\begin{array}{l}\text { - Obtain consent for the project } \\
\text { - Decide about the extent of the study area }\end{array}$ & 2 & $\begin{array}{l}\text { Board of traditional } \\
\text { Saamaka authorities }\end{array}$ & 3 & 6 & $\begin{array}{l}\text { Community consultation meeting } \\
\text { (Schreckenberg et al., 2014) }\end{array}$ & $\begin{array}{l}\text { April } \\
2014 / \\
\text { June } \\
2015\end{array}$ \\
\hline Community meeting & - Obtain informed consent & 4 & $\begin{array}{l}\text { Local authorities, } \\
\text { village committees, } \\
\text { local community } \\
\text { members }\end{array}$ & 39 & 90 & $\begin{array}{l}\text { Community consultation meeting } \\
\text { (Schreckenberg et al., 2014) }\end{array}$ & $\begin{array}{l}\text { May } \\
2014 / \\
\text { July 2015 }\end{array}$ \\
\hline \multirow[t]{2}{*}{ Participatory GIS } & - Building blank relief model & 2 & $\begin{array}{l}\text { Children and } \\
\text { youngsters from } \\
\text { Saamaka villages }\end{array}$ & 32 & 18 & \multirow[t]{2}{*}{$\begin{array}{l}\text { Participatory 3D Modelling (P3DM) } \\
\text { (Rambaldi \& Callosa-Tarr, 2001) }\end{array}$} & $\begin{array}{l}\text { July } \\
\text { 2014/ } \\
\text { August }\end{array}$ \\
\hline & - Actual mapping activities & 2 & $\begin{array}{l}\text { Elderly and adults from } \\
\text { various Saamaka } \\
\text { villages }\end{array}$ & 21 & 84 & & 2015 \\
\hline \multirow[t]{3}{*}{$\begin{array}{l}\text { Focus groups } \\
\text { discussions }\end{array}$} & - Elucidate map legend items & 6 & $\begin{array}{l}\text { Elderly and adults from } \\
\text { various Saamaka } \\
\text { villages }\end{array}$ & 30 & 80 & $\begin{array}{l}\text { Free listing (Schreckenberg et al., } \\
\text { 2014) }\end{array}$ & $\begin{array}{l}\text { July } \\
\text { 2014/ } \\
\text { July 2015 }\end{array}$ \\
\hline & - Cross-check and validate information & 6 & $\begin{array}{l}\text { Elderly and adults from } \\
\text { various Saamaka } \\
\text { villages }\end{array}$ & 22 & 78 & $\begin{array}{l}\text { Free interaction organized in } \\
\text { groups (Schreckenberg et al., 2014) }\end{array}$ & $\begin{array}{l}\text { July } \\
2014 / \\
\text { October } \\
2015\end{array}$ \\
\hline & $\begin{array}{l}\text { - Gather perception of change in supply and } \\
\text { demand of ecosystem services } \\
\text { - Prioritize ecosystem services } \\
\text { - Gather information about land use, natural } \\
\text { resource management }\end{array}$ & & $\begin{array}{l}\text { Elderly and adults from } \\
\text { various Saamaka } \\
\text { villages }\end{array}$ & 8 & 52 & $\begin{array}{l}\text { A mixture of Multidisciplinary } \\
\text { Landscape Assessment (MLA) } \\
\text { methods (Liswanti \& Basuki, 2009) }\end{array}$ & $\begin{array}{l}\text { July } 2014 \\
\text {-Dec } \\
2015\end{array}$ \\
\hline Interviews & $\begin{array}{l}\text { - Explore the views of external stakeholders } \\
\text { regarding the utility of the P3DM approach in } \\
\text { the socio-economic context of the USRB }\end{array}$ & 32 & $\begin{array}{l}\text { Ministry of Regional } \\
\text { Development, } \\
\text { District commissioner, } \\
\text { Forest service, } \\
\text { NGO's, } \\
\text { University, } \\
\text { Private sector }\end{array}$ & - & - & Self-administered questionnaires & $\begin{array}{l}\text { February } \\
2016\end{array}$ \\
\hline
\end{tabular}




\begin{tabular}{|c|c|c|c|c|}
\hline sarmakatong & & Nederleads & Sanamake Tonga & Nederleads \\
\hline BAliGoon & - & Voethal veld & PASI & Looppad 1 \\
\hline KalanG WAtA & 3 & Waterleiding & WPGI PASI $=$ & Autoveg \\
\hline GoonbasuWATA & $\cdot$ & Water bron & kilki di ta kdi & Seizonsikneck \\
\hline GEE bi & 2 & Beyrayplacts & Kiki di na takod & - Permaneate kurk \\
\hline Faja wosu & 3 & Genentar theis & GAAN kiki & Kreak grout gandy un betan \\
\hline Siko & . & School & Piki kiki & 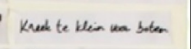 \\
\hline imdentaryt & 2 & Kostgronaje Kamp & $\mathrm{LO}$ & Rivier \\
\hline Poti ${ }^{-10}$. & - & Polittiniek & GAAN DANG - & Grote tromansinelling \\
\hline$S \in m b \in(10)$ & & Inwoners (10) & Piki DANG - & Kleine stroomensnelling \\
\hline$S<m b \in(100)$, & - & Inworees $(100)$ & mEER & Meer \\
\hline Sembe $(500)$ & $=$ & Inwoners (500) & Goutu baak & Goudmijngebed \\
\hline keiki & - & Kerk & VIA UIA & \\
\hline ToERist Kampu & $l^{*}$ & Tonnistakamp & MASIA MASIA & \\
\hline moetie oflib & $b a$ & Faums wauneer pas & Paw Matu & Primair bos \\
\hline Hondi Kampu & $=$ & ragenskemp & KaPëe MaTu & Secundare ber \\
\hline LAMPESI & $\cdot$ & Aarly-wan a visplests & Kapëe $\mathbf{E}$ & Verlaten bostgromaje \\
\hline $\begin{array}{l}\text { Wooko KamiA } \\
\text { Opalani goon } \\
\text { Woko Gowtu Ka } \\
\text { Reng u Kamia }\end{array}$ & CAmià & 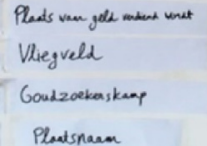 & SANDU BANGI & Zandbank \\
\hline
\end{tabular}

Fig. 2. Map legend in Saamaka and Dutch language used by communities of subregion 1 during P3DM activities.

and women separately. There were a number of elders in each group usually assisted by a younger person who helped writing. Metacards and markers were distributed per group. At the start, we asked to the whole group: "What are the most essential features in the area that serve the needs of the Saamaka people? Please write an item per card and include a short description". When the groups were ready, written metacards were placed on a board, presented and discussed with all the participants to ensure that the list of features was agreed by all. Repeated items were left apart and descriptions of commonly identified items were enriched. The same procedure was completed in each workshop carried out in sub-region 1 and 2 .

\subsection{The map legend}

We grouped the list of landscape features identified into legend items. Symbols were chosen to represent points, lines or polygons.
The final legend was presented to all participants and approved prior to the map-making activities in each sub-region. The agreed list of landscape features to be mapped was visualized on a board and used as a guide during the P3DM activity (Fig. 2).

\subsection{Participatory 3D mapping of landscape features}

Two mapping activities took place in each sub-region using P3DM methods as derived from Rambaldi and Callosa-Tarr (2001). The base map for the P3DM was created from a Digital Elevation Model (DEM) of $30 \mathrm{~m}$ spatial resolution obtained from the Shuttle Radar Topographic Mission (USGS, 2014) from which we conveniently generated $20 \mathrm{~m}$ contour line with the desired size and spatial scale of the model. A spatial scale of $1: 15,000$ was selected to ensure the coverage of the entire area as selected by the local traditional authorities during the inception stages. This resulted in two P3DMs constructed in foam board of $4 \mathrm{~mm}$ thick. They measured $4.8 \mathrm{~m} \times 2 \mathrm{~m}$ for sub-region 1 and $6 \mathrm{~m} \times 1.6 \mathrm{~m}$ for subregion 2. We split the models in 4 and 5 units of $1.2 \mathrm{~m} \times 2 \mathrm{~m}$ and $1.22 \mathrm{~m} \times 1.60 \mathrm{~m}$ each respectively for sub-region 1 and sub-region 2.

The P3DM activity started with the constructions of a blank model by children and youngsters and continued with local knowledge holders (i.e. elders and adults) who mapped the legend items using a color-coded system consisting of push pins to represent point features (Fig. 3). Water-based color paint was used to represent land cover types and to draw line features (roads, trails and creeks). Once the P3DM was completed, a sequence of highresolution digital photographs was taken from the model following the guidelines specified in Rambaldi (2010) taking care of minimizing radial and relief displacement. These photographs were entered as TIFF raster images in a GIS system where these were first geo-referenced and then digitized using $\operatorname{ArcMap}^{\circledR}$. The images were geo-referenced to the UTM projected coordinate system, Zone $21 \mathrm{~N}$ with an average of 32 ground control points per map piece.

\subsection{Validation of the information by P3DM participants}

We carried out six additional workshops (three in each subregion) to cross-check and validate, together with the participants, the information contained in the P3DM. During these workshops, we presented the digitized maps with the landscape features mapped and asked the participants to check for missing or wrong information, misplaced features and misspelled words. This was an important step to reinforce the ownership of the P3DM
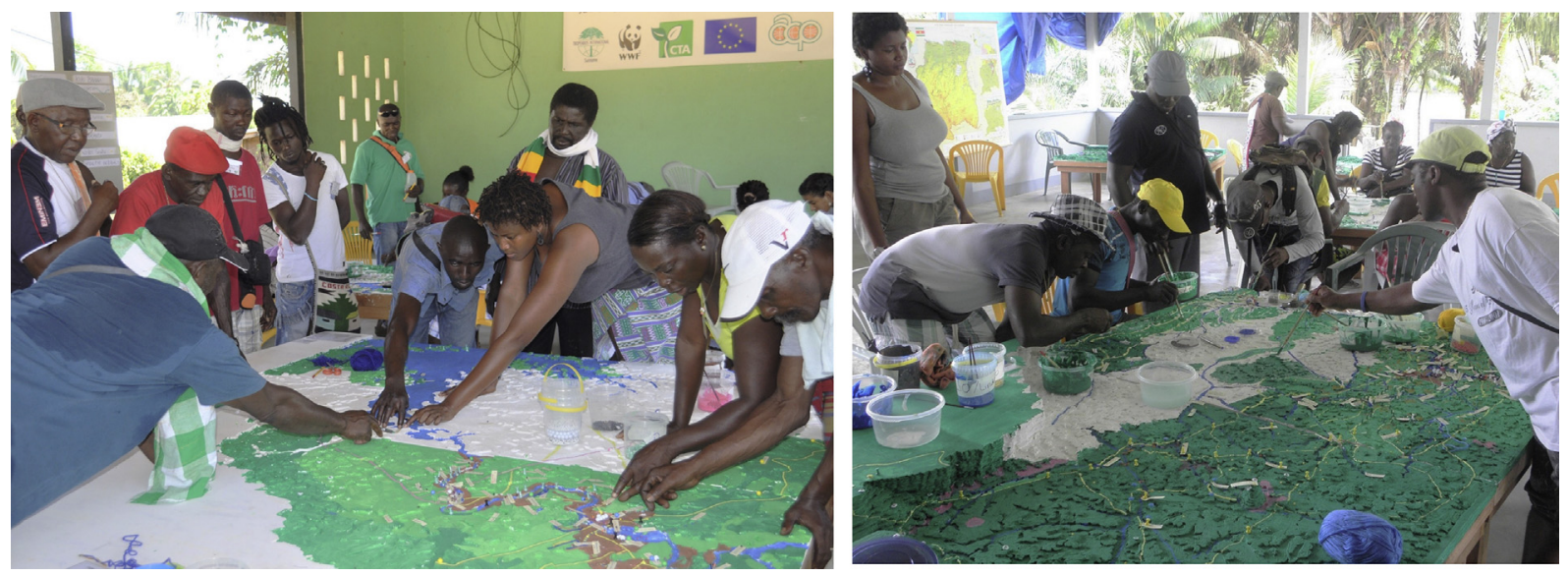

Fig. 3. Group of community participants from sub-region 1 (left) and sub-region 2 (right) mapping landscape features on the 3D map in progress. 
outputs by local communities and to engage them in the following up stages of the ecosystem services assessment described below.

\subsection{Typology of ecosystem services}

We classified the identified landscape features into ES according to the typology of the Common International Classification of Ecosystem Services (CICES) (Haines-Young \& Potschin, 2011; Vallés-Planells et al., 2014). The original typology contains three broader ES categories: 1) provisioning, 2) regulation and maintenance and 3) cultural and social. These categories are divided into 13 ES classes: nutrition, material, energy, daily activities, regulation of waste, flow regulation, regulation of physical environment, regulation of biotic environment, regulation of spatial structure, health, enjoyment, self-fulfillment and social fulfillment. For this study, we included 11 classes (Table 2) as these were considered relevant by the participants.

\subsection{Prioritization of ecosystem services}

The participants discussed the list of classified ES during six FGDs (three in each sub-region). Once they agreed with the classification, we asked them to start with the prioritization by means of the Pebble-Distribution method (Colfer et al., 1999). Using a panel of illustrations for each ES, the participants were prompted to distribute 100 pebbles among the illustrations based on their perception of importance for their ways of life. The more pebbles an ES illustration would get, the more important it was perceived to be. Participants explained the reasoning behind the final scores and the different opinions were discussed by the entire participants group and the relative scores were averaged from all groups of participants in each of the sub-regions.

\subsection{Perception of change in the supply of important ecosystem services}

We also asked the participants to discuss their perceptions of change in the supply of those prioritized ES over the last three decades or more depending on the timeline that participants remembered. Opinions were rated from 0 to 10 where 10 represented a period of abundance while lower rates represented different degrees of scarcity. During the exercise, informants discussed which were the factors underlying change and the implications for their traditional livelihoods and wellbeing.

\subsection{Change in the demand of ecosystem service use}

Similarly, the use of certain ES has changed over time according to different factors. To assess these changes, respondents indicated during FGDs, the current use of those prioritized ES as compared to the past (to refer to the past we ask them to think back to the time when their grown up children were small) using a scale of five categories: not used anymore, rarely used, occasionally used, regularly used and used often.

\subsection{Assessment of the usefulness of the approach in the context of the USRB}

We collected the views of both external and local stakeholders regarding the usefulness of the P3DM approach to an ES assessment among the Saamaka communities. To appraise the opinion of external stakeholders, we conducted 32 interviews among civil society organizations, governmental institutions, communitybased organizations, extractive industries and NGOs by asking the following questions: 1) Comparing P3DM with other methods implemented, what is, in your opinion, the main value of the P3DM process and outcomes in Suriname? 2) Could you please select a maximum of three situations in which the P3DM is useful in the context of the Upper Suriname River Basin? By contrast, the views of local stakeholders were appraised through anecdotal evidence, in situ conversations, field notes and sound recordings.

\section{Results}

\subsection{Identification of landscape units}

The P3DM mapping process resulted in two local communitiesvetted maps for each sub-region (Fig. 4). The total landscape area is 176,860 ha and 198,910 ha for sub-region 1 and 2 respectively. The maps contain 11 landscape units which are described in Table 3. These units were identified by the community participants reflecting both their landscape knowledge and their use of the area. For example, $\mathrm{Pu}$ (swamp) might exist in more locations across the study area but only those that are actually known or are in use have

Table 2

Typology of ecosystem services adjusted to match the ES identified during this study.

\begin{tabular}{|c|c|c|}
\hline Theme & Ecosystem service class & Description \\
\hline \multirow[t]{4}{*}{ Provisioning $(\mathrm{P})$} & Nutrition & $\begin{array}{l}\text { Plant and animal food sources found in terrestrial, freshwater and marine ecosystems. Includes } \\
\text { potable drinking water. }\end{array}$ \\
\hline & Material & Biotic and abiotic materials. \\
\hline & Energy & Renewable fuel sources. \\
\hline & Daily activities & $\begin{array}{l}\text { Residential space, space where people develop a job and spatial communication paths that allow } \\
\text { people to commute, travel or just access other services. }\end{array}$ \\
\hline \multirow[t]{3}{*}{ Regulation and maintenance (R) } & Flow regulation & Water flow regulation. \\
\hline & Regulation of the biotic environment & Ecosystem maintenance and habitat protection \\
\hline & Regulation of the spatial structure & $\begin{array}{l}\text { Refers to the ways that landscape configurations ensure the provision of other services for } \\
\text { present and future generations. For example connectivity between habitats and ecosystems. }\end{array}$ \\
\hline \multirow[t]{4}{*}{ Cultural and social $(C \& S)$} & Health & Contribution to the enhancement of mental and physical health. \\
\hline & Enjoyment & $\begin{array}{l}\text { Opportunities for aesthetic appreciation and recreation. Commensurate with tourism } \\
\text { opportunities. }\end{array}$ \\
\hline & Self-fulfillment & $\begin{array}{l}\text { Includes: 1) landscape referents that enhance spatial orientation. 2) Provision of sites that have } \\
\text { learning opportunities. } 3 \text { ) Spiritual experience through the provision of sacred places for } \\
\text { religious practices or sites connected to legends or myths. 4) Landscape elements that are source } \\
\text { of inspiration for culture. }\end{array}$ \\
\hline & Social fulfillment & $\begin{array}{l}\text { Includes: 1) Places in the landscape, different from home and work that provide opportunities } \\
\text { for social interactions. 2) Places in the landscape that contribute to shaping of community's } \\
\text { cultural identity. 3) Provision of stable referent points through the life course. }\end{array}$ \\
\hline
\end{tabular}




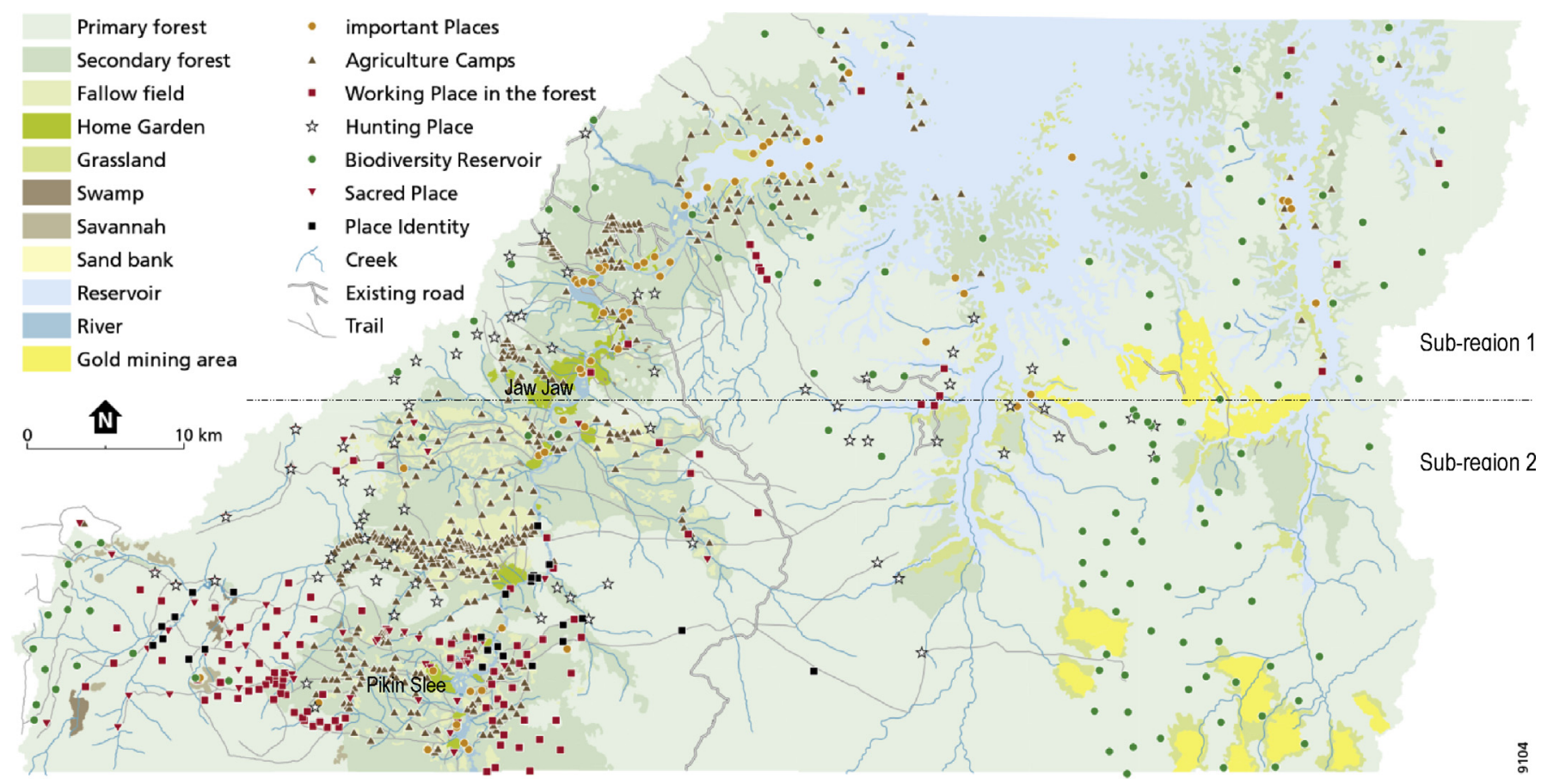

Fig. 4. Map georeferenced and digitized from the P3DM in both sub-regions depicting landscape units and mapped ES.

been mapped. In terms of extent, the largest area is occupied by primary forest in both sub-regions covering $45 \%$ in sub-region 1 and $73 \%$ in sub-region 2 . One contrasting difference among subregions is the extent of the field in fallow (kapeë) where local communities harvest palm oils. The extent of this landscape unit per inhabitant is estimated at 0.07 and 6.6 ha for sub-region 1 and 2 respectively.

\subsection{Identification of landscape features and classification into ecosystem services}

The landscape features reported by the communities varied slightly among sub-regions. A total of 36 landscape features were identified during the P3DM process and further classified into ES. Most differences among sub-regions are related to cultural services under the category of self and social fulfillment (Table 4).

\subsection{Prioritization of ecosystem services}

The order of importance of ES varied according to the background and interest of the community participants in each subregion. For example, in sub-region 1, the highest importance was adhered to few ES such as timber, crops, medicinal products and wild meat which have income generation value according to the views of participants during focus groups discussions. In sub-region 2 , participants assigned relatively high values to feeling of attachment, medicinal products, crops and timber. Table 4 summarizes the relative weights assigned by participants in each sub-region. Noticeable, ES such as drinking water, forest, biodiversity areas, religious areas, cemeteries, churches, football fields and important places received, deliberately, no weight given the intrinsic value that these features have according the perception of local community participants expressed during the workshops.
Table 3

Landscape units digitized from the P3DM both in sub-region 1 (S1) and sub-region 2 (S2).

\begin{tabular}{|c|c|c|c|c|}
\hline \multirow[t]{2}{*}{ Local name } & \multirow{2}{*}{$\begin{array}{l}\text { English } \\
\text { name }\end{array}$} & \multirow{2}{*}{$\begin{array}{l}\text { Brief description (based on local } \\
\text { narratives) }\end{array}$} & \multicolumn{2}{|l|}{$\%$} \\
\hline & & & S1 & S2 \\
\hline Paw Matu & $\begin{array}{l}\text { Primary } \\
\text { forest }\end{array}$ & $\begin{array}{l}\text { Forest with big trees where there has not } \\
\text { been shifting cultivation. }\end{array}$ & 45 & 73 \\
\hline Kapëe matu & $\begin{array}{l}\text { Secondary } \\
\text { forest }\end{array}$ & $\begin{array}{l}\text { Forest that was cleared for shifting } \\
\text { cultivation } \\
\text { in the past and that has regenerated into } \\
\text { forest. }\end{array}$ & 20 & 18 \\
\hline Kapëe & Fallow field & $\begin{array}{l}\text { Abandoned shifting cultivation sites } \\
\text { were } \\
\text { palm fruits are continuously harvested. }\end{array}$ & & 3 \\
\hline Mäsiä mäsiä & Grassland & $\begin{array}{l}\text { Area around the lake where only grassy } \\
\text { vegetation grows. }\end{array}$ & 1 & 0,3 \\
\hline Via via & $\begin{array}{l}\text { Home } \\
\text { garden }\end{array}$ & $\begin{array}{l}\text { Area around houses with some perennial } \\
\text { crops and fruit trees. }\end{array}$ & 2 & 1 \\
\hline $\mathrm{Pu}$ & Swamp & $\begin{array}{l}\text { A place in the forest that collects rainfall } \\
\text { water that flows to creeks. }\end{array}$ & 0,1 & 0,2 \\
\hline Savanna & Savanna & $\begin{array}{l}\text { A natural place in the forest with no big } \\
\text { trees. }\end{array}$ & 0 & 0,2 \\
\hline Sandu bangi & Sand bank & $\begin{array}{l}\text { Places in the river where sand is } \\
\text { accumulated. }\end{array}$ & 0,1 & 0,1 \\
\hline Meer & $\begin{array}{l}\text { Brokopondo } \\
\text { reservoir }\end{array}$ & $\begin{array}{l}\text { Artificial lake for hydropower } \\
\text { generation }\end{array}$ & 29 & 2 \\
\hline Lio & River & River and river arms & 1 & 0,4 \\
\hline Gowtu baakoe & $\begin{array}{l}\text { Gold mining } \\
\text { areas }\end{array}$ & $\begin{array}{l}\text { Areas where gold mining activities take } \\
\text { place }\end{array}$ & 2 & 2 \\
\hline
\end{tabular}

\subsection{Change in the supply and demand of important ecosystem} services

Local views related to a change in the demand of ES show differences among sub-regions. For example the demand for agriculture and fish has decreased in sub-region 1 while in sub-region 2 these are still highly demanded. Anecdotic evidence suggest that the decrease in the demand of the ES is related to degradation of the source, out migration, loss of traditional ecological knowledge 


\begin{tabular}{ll}
\hline P Nutrition & \\
1 & Crops \\
2 & Wild meat \\
3 & Palm oils \\
4 & Fish \\
5 & Wild fruits \\
6 & Spices \\
7 & Drinking water \\
P Material & \\
8 & Timber \\
9 & Thatching materials \\
10 & Binding materials \\
11 & Fibers \\
& \\
12 & Quarry \\
13 & Soil \\
14 & Resins \\
P Energy & Firewood \\
15 & Paily activities \\
16 & Place to live: Village \\
17 & Place to move: Trails \\
18 & Place to move: Roads \\
19 & Place to move: tractor ways \\
20 & Place to move: Rivers \\
R Water flow regulation \\
21 & Swamps
\end{tabular}

Njang njang goön
Matu gwamba
Fatu (u boï sondi)
Fisi
Matu fuuta
Uwii/son di boï
Wata u bebe
Paw u wöoko
Tasi
Tatai mbei wosu
Uwiï u mbei sondi
Tjatja/Sandu
Doti
Paw kandea
Faja udu
Konde
Pasi
Wagi pasi
Koni pasi
Lio
Pu

Mbeti liba

Paw matu

Desi uwii

Gaan dang and kule wata Toerist kampu

Faka pau

Wasi moii or tjangaa

Lampesi

Bali goön

Keeki

Geebi

Taku kamian

Sacred place

Place identity

Feeling of attachment.

Important place
Crops under shifting cultivation both in primary and secondary forest

Animals hunted in the forest for food and for income generation

Oils extracted from palm fruits and used for cooking and other uses such as ceremonies/rituals

Fish found in rivers, creeks and swamps and used for subsistence and income generation

Fruits found in the forests

Herbs and spices used for cooking

Drinking water sources from creeks and rivers

For construction of houses, boats and kitchen utensil, crafts and for income generation purposes Woven palm leaves used for roofing

Liana used as a binding material in the construction of houses

Gourds, reeds, wild cotton and palm leaves used for making clothes, rope, hand crafts, kitchen utensils and elements for rituals

Sand and gravel for the construction of houses and for income generation purposes

Type of soil used in construction of houses

Type of resins from certain tree used to light fires

Firewood for cooking

Village

Includes walking trails between villages, hunting trails and trail to the river

Roads where cars can drive

Trails were a tractor can go

Main transport hub in the area

Areas in the primary forest were water accumulates

Areas in the primary forest that are important for wildlife and for the protection of other resources

Large tracts of connected primary forests providing connectivity and a reservoir of resources for future generations

Medicinal products obtained deep in the primary forests

Rapids were children can play

Lodges were tourists stay, usually situated in areas that are attractive for tourism

Area for ritual performance inside the village

Area for ritual performance in the forest

Special place in the river bank or creek, or large stones in the river where women gather to wash dishes, to bathe and to fish

Place in the village where men gather to play football while other people gather around the field for amusement.

Place in the village to worship according to a Christian religion

Burial area around the village for community members

Place that preserves ancestral memory

Special places in the forests that are essential to preserve Saamaka culture and traditions

Literally translate as "earth" but it describes a feeling of belonging to the land

River islands, river stones, camps, rapids, and other places that are important for various reasons 
Table 5

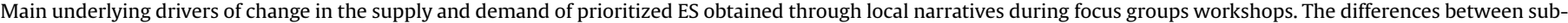
regions are indicated with S1 (sub-region 1) and S2 (sub-region 2).

\begin{tabular}{|c|c|c|c|c|c|c|}
\hline \multirow{3}{*}{$\begin{array}{l}\text { Ecosystem } \\
\text { service }\end{array}$} & \multicolumn{4}{|c|}{ Trend } & \multicolumn{2}{|l|}{ Underlying drivers of change } \\
\hline & \multicolumn{2}{|c|}{ Demand } & \multicolumn{2}{|c|}{ Supply } & \multirow[t]{2}{*}{ Demand } & \multirow[t]{2}{*}{ Supply } \\
\hline & $\mathrm{S} 1$ & $\mathrm{~S} 2$ & $\mathrm{~S} 1$ & $\mathrm{~S} 2$ & & \\
\hline Crops & + & ++ & $\nabla$ & $\boldsymbol{\nabla}$ & $\begin{array}{l}\text { S1: lack of interest and out migration of young } \\
\text { and capable people leaving aged persons who } \\
\text { are less and less able to open up new crop areas }\end{array}$ & $\begin{array}{l}\text { Decreasing soil fertility due to shorter fallow } \\
\text { periods }\end{array}$ \\
\hline Wild meat & + & + & $\nabla \nabla$ & $\nabla \nabla$ & $\begin{array}{l}\text { Smaller mammals and birds that are found } \\
\text { easier are commonly the source of protein. } \\
\text { Larger animals are hunted with greater effort } \\
\text { for ceremonies and occasionally for income }\end{array}$ & $\begin{array}{l}\text { Large mammals have declined due to high } \\
\text { hunting pressure, also, noise from tractors, } \\
\text { chain saws and other disturbances by human } \\
\text { presence }\end{array}$ \\
\hline Palm oils & + & + & $\Delta \boldsymbol{\Delta}$ & $\Delta \boldsymbol{\Delta}$ & $\begin{array}{l}\text { S1: Used more and more for ceremonies and } \\
\text { rituals only } \\
\text { S2: Used on a daily base for cosmetic purposes } \\
\text { and for income generation but wide use for } \\
\text { cooking is decreasing, people buy in the store } \\
\text { due to amount of work }\end{array}$ & $\begin{array}{l}\text { No change, it is still abundant throughout fields } \\
\text { in fallow }\end{array}$ \\
\hline Fish & + & ++ & $\nabla \nabla$ & $\nabla \nabla$ & $\begin{array}{l}\text { On a subsistence basis people are depending } \\
\text { more on smaller fish with less nutritional value. } \\
\text { Obtaining larger fish currently demands larger } \\
\text { distances, more costs, time and effort }\end{array}$ & $\begin{array}{l}\text { Decline of fish with high economic and } \\
\text { nutritional value due to unsustainable fishing } \\
\text { practices }\end{array}$ \\
\hline Timber & ++ & ++ & $\nabla \nabla$ & $\boldsymbol{\nabla}$ & No change. It is still widely demanded & $\begin{array}{l}\text { S1: Stocks reduced due to high pressure from } \\
\text { commercial logging } \\
\text { S2: Increased pressure for the construction of } \\
\text { boats and houses }\end{array}$ \\
\hline $\begin{array}{l}\text { Forest } \\
\text { medicines }\end{array}$ & + & + & $\boldsymbol{\nabla}$ & - & $\begin{array}{l}\text { Loss of traditional knowledge about medicinal } \\
\text { plants. People are also } \\
\text { relying more on western medicines }\end{array}$ & $\begin{array}{l}\text { No change, it is still abundant throughout } \\
\text { primary forests }\end{array}$ \\
\hline
\end{tabular}

$\Delta \Delta$ Abundant.

$\boldsymbol{\nabla}$ Severe decline.

$\checkmark$ Moderate decline.

- No change.

++ High demand.

+Moderate to low demand.

and changes in life styles, i.e. people are buying more at the local store. Furthermore, local perceptions indicate that there is a severe decline in the supply of fish, wild meat and commercial timber species in sub-region 1 and of wild meat and fish in sub-region 2. Crops and fibers are perceived to have declined moderately in both sub-regions. Forest medicines have declined in sub-region 1 while these have remained unchanged in sub-region 2. Main reasons for these changes relate to over-exploitation of the ES. Table 5 presents a summary of the underlying reasons explaining change.

\subsection{Usefulness of the approach in the context of the USRB}

\subsubsection{According to external stakeholders}

The opinions of external stakeholders regarding the utility of the P3DM in the context of the Saamaka territory are reflected in Table 6. Most opinions coincide that compared to previous methods used, the added value of the P3DM is related to the ownership of the process and the resulting information by the local communities as well as the opportunity to produce maps with cartographic accuracy in collaboration with community participants. Concerning the usefulness of the P3DM process among distrustful communities, stakeholders indicated multiple opportunities for application where the approach might best fit. For example, stakeholders indicated that it would be applicable for the management of land use conflicts constrained to the Saamaka territory, for supporting land tenure claims and for enabling a legitimate participation of Saamaka communities in REDD + related projects. However, diverging opinions suggested the need to increase accessibility of physical 3D models for a larger diversity of users of the area as well as access to digital GIS data so that it can be used widely in land use planning. Communication mechanisms in support of the accessibility and usability of the P3DM data also need to be established and maintained.

\subsubsection{According to local communities}

We grouped local narratives regarding the utility of the P3DM according to the following three aspects: a tool for advocacy, a tool for learning spatial planning and a tool to transfer traditional

Table 6

Usefulness of the P3DM in the context of the USRB according to external stakeholders. Percentage of respondents is relative to $\mathrm{N}=32$.

What is the added value to of the P3DM when compared to previous methods implemented?

The co-production of knowledge with cartographic accuracy

The ownership of the information and the process by the local communities

In the P3DM the information is more complete and more accurate than in the previous ones

The 3rd dimension, as it allows a bird-eye view which in turns enables discussions and participation

The engagement of the local people in a relative short time among the Saamaka people?

To manage land use conflicts bounds to the Saamaka territory, particularly regarding logging, infrastructure and mining

For supporting land rights claims of the Saamaka people

For an active and transparent participation of the Saamaka people in REDD + related projects

For documenting and safeguarding the knowledge of the Saamaka people

For the implementation of Free Prior Informed Consent in the area when planning interventions 


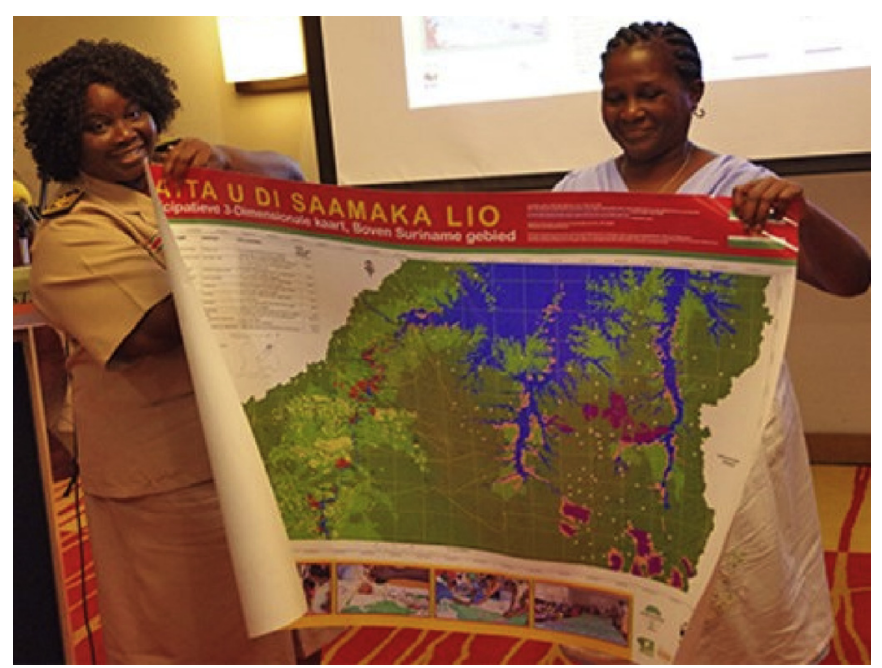

Fig. 5. Saamaka woman (right) handing the map generated during the P3DM process to the district commisionaire (left).

ecological and cultural knowledge.

\section{- An advocacy tool}

The community participants, including local authorities and local leaders expressed that the P3DM process and the maps generated from it have become an important mean to support multi-stakeholders dialogues on issues that affect the Saamaka people:

"Is this map going to be recognized by the government? In that way the areas that are important to us can ultimately be protected from activities wherein we have no voice..."

Trying to address this, members of the Saamaka communities pursued, during a public event organized with external stakeholders (Fig. 5), the formal recognition of the outputs of the P3DM process on behalf of the Surinamese government thereby respecting the ecosystem services important for livelihoods of the Saamaka communities in land use decision making.

\section{- A tool for learning spatial planning}

A key point of the P3DM in terms of the utility for the local communities is the learning opportunity in spatial planning issues. The participants indicated that the map is useful for them to understand better the impacts of road infrastructure:

"When they were going to extend the road to Pusugrunu there was a consultation meeting with us and we all said yes because since we did not have a good map we did not know exactly what and where would be the consequences of that road. But now we have this map and now we can take more informed decisions because we can see and show directly the consequence that the road will have on our land".

Furthermore, local authorities mentioned that the map could be

\footnotetext{
${ }^{1}$ More details of this event can be found in the blog: Being on a map means to exist: the Saramaccan experience http://www.cta.int/en/article/2016-03-08/ saramacca-communities-in-suriname-seek-governmentrs-recognition-of-theirtraditional-knowledge.html.
}

used for land zoning negotiation among clans and a support platform in dialogues with outsiders regarding local forest management structures:

"The map will be useful for local planning in order to reduce conflicts because in our way of thinking forests lands belong to 'lo's (clans) not to villages. So if a community forest is awarded to a villages where the captain (village chief) is from one 'lo' automatically you can have conflicts with other lo's. So this map will be an important visualization and communication tool among us".

\section{- A tool for transfer of traditional ecological and cultural knowledge}

A concern among the Saamaka people is that top-down decisions are taken often to the detriment of the communities because of a lack of awareness and knowledge of the things that are important to them. This concerns a lack of knowledge not only by outsiders, but especially by young community members, which is partly due to the fact that Saamakans do not have a written but an oral tradition. A Saamaka chief addressed this issue during a workshop session:

"This is the time to do something on our own, change our minds and do things ourselves. Let us not allow that something like the Brokopondo dam happens to us again, we lost a lot then because our ancestors did not leave anything written about important places. We need to be better prepared when change arrives and the way to be prepared is to have information of the areas that are important to us, so let us use this map as legacy to the future generations so they can know and understand things better".

\section{Discussion}

In applying the P3DM approach for the participatory assessment of ecosystem services to inform a more inclusive and sound land use planning policy in data scarce and marginalized regions of Suriname, we found evidence of the utility of the approach to engage with local communities that spur distrust and opposition towards outsiders. Because of the reservations by local community members in our study area, the beginning of the ecosystem service assessment was time consuming, requiring several meetings with traditional authorities and local leaders. Their concerns helped improving the methodological approach to be used. We felt it needed to render tangible outputs and outcomes that would influence land use decision making. Specifically, outcomes that would help communities to protect their territory from impacting land use activities (i.e. logging, infrastructure developments) and outcomes that would explicitly support them in their land tenure claims. The critical question posed by traditional Saamaka leaders and which made us decide for the P3DM approach was: "how is this project different from those implemented in the past and what is the added value of the new map compared to existing maps?" This kind of question has been posed by other marginalized communities across the tropics who see the uncertainty of the solutions proposed by more exclusionary approaches (Folke, Hahn, Olsson, \& Norberg, 2005). Therefore, in the following sessions we provide an answer by discussing the various indicators of the utility and added value of the P3DM approach in ecosystem service research among wary communities.

\subsection{A socially engaging tool}

The participation scheme, the time invested in the process, the 
third dimension and the size of the model suggest that P3DM is explicitly designed to be socially engaging, thereby enhancing participatory production and exchange of ecosystem service knowledge which are pre-requisite for effective integration of ecosystem services into decision making as also suggested in Reyers et al. (2015).

\subsubsection{The scheme of participation}

In the P3DM process (legend making and actual mapping), the scheme of participation had a positive effect on discussion time, validation of the information and ownership. Discussions usually lasted 1.5 days, ensuing sufficient time for free and open deliberations about ecosystem services, values, preferences and drivers of change. Time for meaningful discussions may increase social equity and legitimacy of the outcomes of ecosystem service assessments (Wilson \& Howarth, 2002). By contrast, other participatory mapping activities, like those undertaken in other places of Suriname and Colombia (Ramirez-Gomez et al., 2015, RamirezGomez, Brown, Verweij, \& Boot, 2016), took usually three hours, limiting the amount of information that could be obtained. Furthermore, the scheme of participation permitted an overlap of half a day between outgoing and incoming groups which provided time for joint discussions and validation of the information. This represented an efficient way to achieve a robust triangulation of the data. It also added legitimacy to the P3DM by making sure the production of the information and technology was respectful of the diverging values and beliefs of all local community participants as outlined also by Cash et al. (2003). However, there were challenges and drawbacks with respect to the participation of the Saamaka women. In practice, it turned out that a P3DM process, as well as other PGIS tools (McCall \& Minang, 2005) is influenced by existing power and gender structures within tribal and indigenous groups, limiting the equal representation of values of all community participants.

\subsubsection{The third dimension}

The bird's-eye view of the area and the relief effect enabled a holistic visualization of the entire area which had an effect of stimulating an interactive participation of men and women, children young, adults and elders, who quickly understood the map regardless their literacy level. They spontaneously reflected on conflicting landscape interests and their effects on sources of important ecosystem services without the assistance of the team of researchers. The $3 \mathrm{D}$ view also incited discussions on multiple perspectives concerning aspirations, worries and trade-offs of development and its effects on well-being. By contrast, as pointed out by Fagerholm, Käyhkö, Ndumbaro, and Khamis (2012), a particular challenge for PGIS methods is the accurate representation of the spatial dimension of the mapped landscape attributes in relation to the often abstract nature of the background maps. This in turn increases the time and demands more skills from the participants and local facilitators to understand the images. Interestingly, using aerial photograph as background map have proven to be successful in other PGIS studies as landscape features can be easily recognized by the PGIS participants (Fagerholm et al., 2012). However, the fact that participants manufacture the 3D models themselves constitutes a boundary activity that enhances the collective learning process, information retrieval, harnesses critical thinking and subsequently leads to a more interactive knowledge co-production. These findings are in line with outcomes in other studies by Castella (2009) and Bourgoin, Castella, Pullar, Lestrelin, and Bouahom (2012).

\subsubsection{The size of the models}

The large size of models could accommodate a larger amount of participants as usually there should not be more participants than those that can fit around the map or model (Rambaldi \& CallosaTarr, 2001). Likewise, a large model size resulted in a better inclusion of many important places across a larger territorial extent. Participants indicated that usually maps of the Saamaka territory are restricted to a fringe along the river, excluding many areas of use. By contrast, they mentioned that the extent of the P3DM map represented the area claimed as Saamaka territory.

Despite the evidence of P3DM as a socially-engaging process, our approach was limited in the involvement of policy makers and other external stakeholders. Our P3DM approach was primarily oriented towards the empowerment of Saamaka communities to participate in land use decision making. However, as debated by various scholars (Fischer et al., 2015; Guerry et al., 2015; Knight, Cowling, \& Campbell, 2006; Reyers et al., 2015) ecosystem service assessments need to be grounded in a collaborative learning process among all stakeholders involved if the purpose is to have a practical impact and effectively mainstream ecosystem services into land use decision making.

\subsection{A user-useful process}

In terms of user-usefulness we can distinguish between direct tangible and mid-to long-term outcomes of the P3DM among Saamaka people in Suriname. The physical 3D models, the digitized map and the information produced during the landscape assessment are among the tangible direct benefits that we highlight.

\subsubsection{The physical $3 D$ models}

The physical P3DM stayed in the communities which was fundamental to increase participants' trust in the project. Usually PGIS outputs need to be taken away from the community and go along with the researcher or project team for further geoprocessing, increasing the expectations of the participants regarding what happens with the information afterwards. In contrast, the physical P3DM model remains in the community and P3DM practitioners take only digital pictures of the model for further analysis. Immediately after the P3DM is created, it becomes an educational tool for the community, especially for children and youngsters. This means that having the model for direct use requires that a space in the village is arranged. This has been challenging in our project due to the large size of the models that were built, hence the P3DMs built have not been yet properly displayed. Nonetheless, community leaders and institutional partners are pursuing conversations with the district commissioner to make a space available within the USRB area for the physical P3DM so that it becomes accessible for all. We suggest thus that future research projects using the P3DM approach, include in their planning, the allocation of a space where the P3DM can be displayed and permanently available.

\subsubsection{The digitized map}

The vetted maps derived from the P3DM process were printed in different formats and distributed among all local traditional authorities, schools and general community members in order to be used for education and communication purposes. Evidence from the field showed that some community members were using the printed version of the P3DM map to communicate with the Forest Service regarding the occurrence of conflicting logging activities inside the territory of a particular village. Thus, the P3DM vetted maps, as well as other visualization means, are necessary in ecosystem service assessments for spatially explicit decision making and monitoring of the consequences of decisions as also pointed by Hauck et al. (2013). This means that the digital version of the maps needs to be also available for policy makers so that they can 
have visual means for understanding how and where the landscape can or cannot be changed in order to enhance the provision of ecosystem services as noted, in a similar fashion by de Groot et al. (2010). In the context of our project, the printed maps were formally presented and distributed to policy makers by local community members as outlined in session 4.5.2; however, policy makers indicated the need to create access to the digital GIS data so that it can be used widely in land use planning. Unfortunately, wide access to the information by local communities and policy makers is still obstructed not only by the lack of capacity to handle GIS data but also due to local bureaucracy regarding who should control access and use of the information.

\subsubsection{Assessment of ecosystem services}

The P3DM process proved to be a valuable approach to enable the collective and efficient generation of comprehensive spatial information that describes and prioritizes the characteristics of the landscape and its services for 24 villages in a relative short time and with the involvement of a wide range of participants. Among the added value of the approach for the characterization of ES is that it provided a more robust insight into the identification of cultural and regulating services as compared with empirical studies in the Amazon region using 2D mapping (Ramirez-Gomez et al., 2015, 2016). In those studies, the concept of ES resulted confusing for the participants which limited the amount of information that could be gathered and depicted on the map beyond tangible provisioning services. By contrast, in this study, once the participants were in front of the 3D representation of the whole landscape, it was natural for them to start making associations between landscape units and the services these provided. For example, certain primary forest areas were indicated on the map as important as reservoirs of biodiversity or "mbeti liba". Swampy areas were also indicated as important for regulating the water that flows to creeks. Similarly, a comprehensive list of cultural services provided by primary forest was retrieved by participants during the mapping activities. The participants decided, however, not to include many of these services in the final map to avoid exposure and risk of profanation.

Thus, we argue that the P3DM output reflects the knowledge system of the Saamaka communities and the close representation of the terrain offers opportunities to reconcile the knowledge systems of the public, policy and science as found by van Noordwijk, Lusiana, Leimona, Dewi, and Wulandari (2013) in landscape studies elsewhere. Finding a common frame of reference and mental models among diverging views of the territory is a key aspect in decision making processes, as was also identified by Sitas et al. (2014). Furthermore, the information generated also reflects the degree of dependency of the Saamaka people on the services provided by the landscape and the value and preferences concerning ecosystem services. In the absence of legally recognized land rights for tribal and indigenous peoples in Suriname, this information can be used to inform policy makers in Suriname in efforts to integrate the protection of livelihoods, culture and traditions into land use plans for the area.

\subsubsection{Assessment of community basic needs}

The P3DM also generated information for every village regarding the presence of drinking water wells, health posts, schools, electricity generators and the size of the population (indicated with push pins of different sizes). This information is absent from official census data (Algemeen Bureau voor de Statistiek in Suriname, 2010) and country reports. Thus, the P3DM becomes a repository of spatially explicit data of community basic needs which can be used in village development plans.

The user-usefulness of the ecosystem service information generated through the P3DM process is fostered when other relevant (external) stakeholders recognize and accept the significance and applicability of the information for spatial planning purposes. In this sense, the presentation event during which the local communities sought government recognition of the maps (Fig. 5) constituted a step towards publicly voicing the concerns of the Saamaka people and, furthermore, towards the acceptance of the map and information by policy makers. Policy makers agreed that the map and the P3DM process present opportunities for managing conflicts related to logging concessions. Arguably, lessons from this work hold significance for the broader application of the P3DM approach for the purpose of free prior informed consent (FPIC) within the USRB with respect to the effect of logging, mining, infrastructure and hydropower generation projects on the livelihoods and culture of the Saamaka communities as have been also advocated by Price (2012b). However, for this to be realized, it is important that in the future, similar projects include a stage in which information is made available to policy makers, through for example, a decision making support platform provided an ethical code for the use of the information is in place.

\subsection{Is a P3DM enough to improve ES outcomes for marginalized communities?}

The usefulness of the map as referred to by the community members and policy makers presents windows of opportunities. The P3DM has potential to function as a boundary object that can be used to bridge negotiation and fair distribution of ES benefits through improved communication and visualization between development planners and the local communities in the USRB. However, at this stage we cannot yet judge the full user-usefulness of the approach in the study area, as clear applications are still lacking. Several issues need to be addressed, such as the ownership of the end products of the P3DM, capacity building of local communities to use the P3DM results in negotiation and decision making processes, and agreement on ethical principles regarding the use of the information by external stakeholders in Suriname. To further ensure the ownership of the P3DM outputs and outcomes by Saamaka communities, it is important that the GIS data generated during the P3DM process are hold by local communities or by a neutral organization so that community members have permanent access to and control over sensitive information (e.g. spatial locations of certain sacred places which were retrieved in the process) (see also McCall \& Dunn, 2012). Additionally, to increase ownership and to guarantee the long-term usefulness of the P3DM outcomes, it is necessary to allocate sufficient time and budget for further training whereby the Saamaka communities build up their skills to manage the information, monitor its use and acquire confidence to become interactive landscape actors.

Moreover, an ethical code for the use of the P3DM information by outsiders as well as by locals needs to be developed and mechanisms in place to implement it in order to avoid overexploitation of the data as has been suggested by Rambaldi, Chambers, McCall, and Fox (2006). This is particularly important in Suriname because it happened during the development of this project, that the P3DM derived information was misused by government officials when a villager sought protection of the forest from logging activities occurring inside the village area. The villager brought up the digitized P3DM map to show the government agency how logging operations were threatening areas that were reserved as future sources of timber. Instead, the government office in charge used the map and the information for extending logging operations inside these important areas under the argument that piece of forest was not in use, since it did not contain any feature indicating that Saamakans use the area (i.e. any point data 
indicating current use for agriculture, hunting, culture, income, or future use). A situation like this may exacerbate distrust, opposition and disempowerment of the Saamaka communities.

While formal tenure rights remain unrecognized by the government institutions, it is therefore recommended that ES assessments using P3DM in similar contexts, include a follow-up stage of participatory spatial planning whereby local communities jointly divide their territory in land use zones representing communal property rights and critical livelihoods systems as suggested by Ostrom (1990) and documented by Ramirez-Gomez et al. (2016). Although zoning itself does not promote sustainability, it might support the negotiation and implementation of commercial land use restrictions (Lambin et al., 2014) or support land use and conservation policies such as the definition of community conserved areas that can help local people in empowering themselves and getting more control over their territory and its resources (Kothari, Corrigan, Jonas, Neumann, \& Shrumm, 2012).

\section{Conclusions and recommendations}

The P3DM approach presented here offers opportunities for conducting collaborative research on ES that is socially engaging and user-useful as recommended by Cowling et al. (2008). These elements are needed in order to enhance ES outcomes for marginalized and disempowered local communities living in remote landscapes under pressure from logging, gold mining and road development projects. We judge the user-usefulness of the P3DM approach to hold significance when local communities without legal tenure rights can use the P3DM outputs as a tangible communication and negotiation tool in full access and control of the local communities involved. For instance, as a means for the thorough implementation of a FPIC designed to achieve social equity in the distribution of the benefits from the use of ecosystem services such as the provision of timber. Operationalizing the userusefulness of the P3DM for FPIC however, is not only a matter of having one. It requires the strengthening of capacities in local communities to judge, control and monitor the outcomes of the process and the use of the information.

Furthermore, lessons from this work suggest the importance that the use of the P3DM approach in ecosystem services assessment includes a zoning of the areas providing ES which should be done in collaboration with local communities. This should include spatially explicit representation of the areas of intrinsic ES value for future generations. Without this evidence, these areas can be interpreted by government or investors, as empty areas that are available for allocation of economic land use activities. Having those areas well-defined provides spatial boundaries against which communities can discuss and negotiate ecosystem service tradeoffs. Overall, the full potential of P3DM in areas where communities lack full legal rights and capacity is most difficult to achieve and can easily fail if local, regional and national institutions (i.e. CBOs, NGO's, civil society and governmental) do not support and formally recognize the P3DM outcomes.

Last but not least, our P3DM approach for the assessment of ES was conceived in the diagnostic phase of a larger program on productive landscapes in the hinterland of Suriname and it was inevitably to raise expectations among the local communities about follow up implementation stages which were beyond the scope of the present study. In this sense, it is important that regardless of the underlying motivation to use P3DM in ecosystem service assessments, the expectations generated by local communities participating in the project need to be considered for the P3DM to be a win-win process for both the researchers and the communities. Usually PGIS tools are conceived in the initiation phases of projects (Brown et al., 2014), however, the need to take the P3DM process beyond the engagement, screening and diagnostic phase of a project has been recognized (Brown \& Kyttä, 2014). Communities expect that their input will not be merely the provision of information but that this information is rather used to influence decisions. Therefore, it is important to embed the P3DM process into a complete operational model from assessment to implementation as reflected in Cowling et al. (2008) if the purpose is to mainstream ES, influence local realities and pursue livelihood resilience in remote and marginalized places.

\section{Acknowledgements}

The authors are grateful to the local community participants from all 24 villages from Pikin Pada until Botopasi who participated in this study. We are grateful for their time, openness and willingness to share their knowledge and concerns. We acknowledge the crucial collaboration of the Association of Saamaka Authorities (VSG) along all the stages of the implementation process. This study made part of a project designed and implemented by Tropenbos International Suriname (Project 13103 LUP) within the Productive Landscapes Program. Financial support was received by WWF Guianas (Grant K-82), Technical Centre for Agriculture and Rural Cooperation (CTA) (Grant agreement 2014-343) and the UNDPGEF-Small Grant Programs (Project SUR/SGP/OP5/Y4/CORE/BD/15/ 47). In addition to the financial support, we thank CTA for the technical assistance and continuous feedback. We thank Deborah Linga for the successful translation and facilitation of the P3DM process and for her contribution to data analysis. We are grateful to Ivan Karnadi (Tropenbos International Suriname) for managing the challenging logistics. Ton Markus prepared the layout of Fig. 4. We are grateful for the useful comments and insights from two anonymous reviewers.

\section{References}

Algemeen Bureau voor de Statistiek in Suriname. (2010). Suriname Demografische data 2004-2010 (Paramaribo).

Ban, N. C., Mills, M., Tam, J., Hicks, C. C., Klain, S., Stoeckl, N., et al. (2013). A socialecological approach to conservation planning: Embedding social considerations. Frontiers in Ecology and Environment, 11, 194-202.

Bennett, E. M., Cramer, W., Begossi, A., Cundill, G., Díaz, S., Egoh, B. N., et al. (2015). Linking biodiversity, ecosystem services, and human well-being: Three challenges for designing research for sustainability. Current Opinion in Environmental Sustainability, 14, 76-85.

Bohensky, E. L., \& Maru, Y. (2011). Indigenous knowledge, science, and resilience: What have we learned from a decade of international literature on "integration"? Ecology and Society, 16(4), 6

Bourgoin, J., Castella, J.-C., Pullar, D., Lestrelin, G., \& Bouahom, B. (2012). Toward a land zoning negotiation support platform: "Tips and tricks" for participatory land use planning in Laos. Landscape and Urban Plannning, 104, 270-278.

Brown, G., Donovan, S., Pullar, D., Pocewicz, A., Toohey, R., \& Ballesteros-Lopez, R. (2014). An empirical evaluation of workshop versus survey PPGIS methods. Applied Geography, 48, 42-51.

Brown, G., \& Fagerholm, N. (2014). Empirical PPGIS/PGIS mapping of ecosystem services: A review and evaluation. Ecosystem Services, 13, 119-133.

Brown, G., \& Kyttä, M. (2014). Key issues and research priorities for public participation GIS (PPGIS): A synthesis based on empirical research. Applied Geography, $46,122-136$

Cash, D. W., Clark, W. C., Alcock, F., Dickson, N. M., Eckley, N., Guston, D. H., et al. (2003). Knowledge systems for sustainable development. Proceedings of the National Academy of Sciences, 100, 8086-8091.

Castella, J.-C. (2009). Assessing the role of learning devices and geo-visualisation tools for collective action in natural resource management: Experiences from Vietnam. Journal of Environmental Management, 90, 1313-1319.

Chaffin, B. C., Gosnell, H., \& Cosens, B. A. (2014). A decade of adaptive governance scholarship: Synthesis and future directions. Ecology and Society, 19(3), 56.

Chambers, R. (2007). From PRA to PLA and pluralism: Practice and theory. Working paper 286. UK: Institute of Development Studies.

Colfer, C., Brocklesby, M. A., Diaw, C., Etuge, P., Günter, M., Harwell, E., et al. (1999). The grab bag: Supplementary methods for assessing human well-being, the criteria \& indicators toolbox series. Jakarta: CIFOR.

Cowling, R. M. (2014). Let's get serious about human behavior and conservation. Conservation Letters, 7, 147-148.

Cowling, R. M., Egoh, B., Knight, A. T., O'Farrell, P. J., Reyers, B., Rouget, M., et al. 
(2008). An operational model for mainstreaming ecosystem services for implementation. Proceedings of the National Academy of Sciences, 105, 9483-9488.

Daw, T., Brown, K., Rosendo, S., \& Pomeroy, R. (2011). Applying the ecosystem services concept to poverty alleviation: The need to disaggregate human wellbeing. Environmental Conservation, 38, 370-379.

Dawson, T. P., Rounsevell, M. D. A., Kluvánková-Oravská, T., Chobotová, V., \& Stirling, A. (2010). Dynamic properties of complex adaptive ecosystems: Implications for the sustainability of service provision. Biodiversity Conservation, 19, 2843-2853.

Fagerholm, N., Käyhkö, N., Ndumbaro, F., \& Khamis, M. (2012). Community stakeholders' knowledge in landscape assessments - mapping indicators for landscape services. Ecological Indicators, 18, 421-433.

Fazey, I., Evely, A. C., Reed, M. S., Stringer, L. C., Kruijsen, J., White, P. C. L., et al. (2013). Knowledge exchange: A review and research agenda for environmental management. Environmental Conservation, 40, 19-36.

Fischer, J., Gardner, T. A., Bennett, E. M., Balvanera, P., Biggs, R., Carpenter, S., et al. (2015). Advancing sustainability through mainstreaming a social-ecological systems perspective. Current Opinion in Environnemental Sustainability, 14, 144-149.

Folke, C., Hahn, T., Olsson, P., \& Norberg, J. (2005). Adaptive governance of socialecological systems. Annual Review of Environment and Resources, 30, 441-473.

García-Nieto, A. P., Quintas-Soriano, C., García-Llorente, M., Palomo, I., Montes, C., \& Martín-López, B. (2015). Collaborative mapping of ecosystem services: The role of stakeholders' profiles. Ecosystem Services, 13, 141-152.

Goodchild, M. F., \& Li, L. (2012). Assuring the quality of volunteered geographic information. Spatial Statistics, 1, 110-120.

de Groot, R. (2006). Function-analysis and valuation as a tool to assess land use conflicts in planning for sustainable, multi-functional landscapes. Landscape and Urban Planning, 75, 175-186.

de Groot, R. S., Alkemade, R., Braat, L., Hein, L., \& Willemen, L. (2010). Challenges in integrating the concept of ecosystem services and values in landscape planning, management and decision making. Ecological Complexity, 7, 260-272.

Guerry, A. D., Polasky, S., Lubchenco, J., Chaplin-Kramer, R., Daily, G. C., Griffin, R., et al. (2015). Natural capital and ecosystem services informing decisions: From promise to practice. Proceedings of the National Academy of Sciences, 112, $7348-7355$

Hahn, T., Olsson, P., Folke, C., \& Johansson, K. (2006). Trust-building, knowledge generation and organizational innovations: the role of a bridging organization for adaptive comanagement of a wetland landscape around Kristianstad, Sweden. Human Ecology, 34, 573-592.

Haines-Young, R., \& Potschin, M. (2011). Common international classification of ecosystem services (CICES): 2011 update. European environmental agency. University of Nottingham. Downloaded 22.8.2015 http://test.matth.eu/content/ uploads/sites/8/2009/11/CICES_Update_Nov2011.pdf.

Hauck, J., Görg, C., Varjopuro, R., Ratamäki, O., Maes, J., Wittmer, H., et al. (2013). "Maps have an air of authority": Potential benefits and challenges of ecosystem service maps at different levels of decision making. Ecosystem Services, 4, $25-32$.

Inter-American Court of Human Rights. (2007). Case of the sarmaka people v. Suriname. Downloaded 11.1.2016 http://www.forestpeoples.org/sites/fpp/files/ publication/2010/09/surinameiachrsaramakajudgmentnov07eng.pdf.

Jankowski, P. (2009). Towards participatory geographic information systems for community-based environmental decision making. Journal of Environmental Management, 90, 1966-1971.

Knight, A. T., Cowling, R. M., \& Campbell, B. M. (2006). An operational model for implementing conservation action. Conservation Biology, 20, 408-419.

Kothari, A., Corrigan, C., Jonas, H., Neumann, A., \& Shrumm, H. (2012). Recognising and supporting territories and areas conserved by indigenous peoples and local communities: Global overview and national case studies. Technical Series. Montreal, Canada: Secretariat of the Convention on Biological Diversity, ICCA Consortioum, Kalpavriksh and Natural Justice.

Kumar, M., \& Kumar, P. (2008). Valuation of the ecosystem services: A psychocultural perspective. Ecological Economics, 64, 808-819.

Lambin, E. F., \& Meyfroidt, P. (2010). Land use transitions: Socio-ecological feedback versus socio-economic change. Land Use Policy, 27, 108-118.

Lambin, E. F., Meyfroidt, P., Rueda, X., Blackman, A., Börner, J., Cerutti, P. O., et al. (2014). Effectiveness and synergies of policy instruments for land use governance in tropical regions. Global Environmental Change, 28, 129-140.

Liswanti, N., \& Basuki, I. (2009). Guidelines for adapted multidisciplinary landscape assessments methods for the management projects in India. Bogor, Indonesia: Center for International Forestry Research (CIFOR).

Lynam, T., De Jong, W., Sheil, D., Kusumanto, T., \& Evans, K. (2007). A review of tools for incorporating community knowledge, preferences, and values into decision making in natural resources management. Ecology and Society, 12(1), 5.

McCall, M. K. (2003). Seeking good governance in participatory-GIS: A review of processes and governance dimensions in applying GIS to participatory spatial planning. Habitat International, 27, 549-573.

McCall, M. K. (2006). Precision for whom? Mapping ambiguity and certainty in (Participatory) GIS. Participatory Learning and Action, 54, 114-119.

McCall, M. K., \& Dunn, C. E. (2012). Geo-information tools for participatory spatial planning: Fulfilling the criteria for "good" governance? Geoforum, 43, 81-94.

McCall, M. K., \& Minang, P. A. (2005). Assessing participatory GIS for communitybased natural resource management: Claiming community forests in Cameroon. The Geographical Journal, 171, 340-356.
McLain, R., Poe, M., Biedenweg, K., Cerveny, L., Besser, D., \& Blahna, D. (2013) Making sense of human ecology mapping: An overview of approaches to integrating socio-spatial data into environmental planning. Human Ecology, 41 $651-665$.

Miller, T. R., Wiek, A., Sarewitz, D., Robinson, J., Olsson, L., Kriebel, D., et al. (2014) The future of sustainability science: A solutions-oriented research agenda. Sustainability Science, 9, 239-246.

Nelson, G. C., Bennett, E., Berhe, A. A., Cassman, K., DeFries, R., Dietz, T., et al. (2006) Anthropogenic drivers of ecosystem change: An overview. Ecology and Society, 11(2), 29.

Newton, P., Miller, D. C., Byenkya, M. A. A., \& Agrawal, A. (2016). Who are forest dependent people? A taxonomy to aid livelihood and land use decisionmaking in forested regions. Land Use Policy, 57, 388-395.

van Noordwijk, M., Lusiana, B., Leimona, B., Dewi, S., \& Wulandari, D. (2013). Negotiation-support toolkit for learning landscapes. Bogor, Indonesia: World Agroforestry Centre (ICRAF), Southeast Asia Regional Program.

Nurmohamed, R., Naipal, S., \& Becker, C. (2008). Changes and variation in the discharge regime of the Upper Suriname River Basin and its relationship with the tropical Pacific and Atlantic SST anomalies. Hydrological Processes, 22, 1650-1659.

O'Faircheallaigh, C. (2013). Extractive industries and indigenous peoples: A changing dynamic? Journal of Rural Studies, 30, 20-30.

Olsson, P., Gunderson, L. H., Carpenter, S. R., Ryan, P., Lebel, L., Folke, C., et al. (2006) Shooting the rapids: Navigating transitions to adaptive governance of socialecological systems. Ecology and Society, 11(1), 18.

Ostrom, E. (1990). Governing the commons: The evolution of institutions for collective action. Cambridge; New York: Cambridge University Press.

Ostrom, E. (2007). A diagnostic approach for going beyond panaceas. Proceedings of the National Academy of Sciences, 104, 15181-15187.

Ostrom, E. (2009). A general framework for analyzing sustainability of socialecological systems. Science, 325, 419-422.

Palomo, I., Felipe-Lucia, M. R., Bennett, E. M., Martín-López, B., \& Pascual, U. (2016) Chapter six - disentangling the pathways and effects of ecosystem service coproduction. In G. W. Bohan, \& D.A. (Eds.), Advances in ecological research ecosystem Services: From biodiversity to society, Part 2 (pp. 245-283). Academic Press.

Pascual, U., Phelps, J., Garmendia, E., Brown, K., Corbera, E., Martin, A., et al. (2014). Social equity matters in payments for ecosystem services. BioScience, 64, 1027-1036.

Poppy, G. M., Jepson, P. C., Pickett, J. A., \& Birkett, M. A. (2014). Achieving food and environmental security: New approaches to close the gap. Philosophical Transactions of the Royal Society B, 369, 20120272.

Price, R. (2012a). Rainforest warriors, human rights on trial. Pennsylvannia Studies in Human Rights. University of Pennsylvania Press.

Price, R. (2012b). Saramaka people $v$ Suriname: A human rights victory and its messy aftermath. Cultural survival. Downloaded 22.1.2016 https://www culturalsurvival.org/news/saramaka-people-v-suriname-human-rights-victoryand-its-messy-aftermath.

Rambaldi, G. (2010). Participatory three-dimensional Modelling: Guiding principles and applications (2010 edition). Wageningen, the Netherlands: CTA.

Rambaldi, G., \& Callosa-Tarr, J. (2001). Participatory 3-D modelling: Bridging the GAP between communities and GIS technology. In International workshop "participatory technology development and local knowledge for sustainable land use in Southeast Asia". Chiang Mai, Thailand.

Rambaldi, G., Chambers, R., McCall, M., \& Fox, J. (2006). Practical ethics for PGIS practitioners, facilitators, technology intermediaries and researchers. Participatory Learning and Action, 54, 106-113.

Rambaldi, G., Kwaku Kyem, P. A., McCall, M., \& Weiner, D. (2006). Participatory spatial information management and communication in developing countries. The Electronic Journal of Information Systems in Developing Countries, 25, 1-9.

Ramirez-Gomez, S. O. I., Brown, G., Verweij, P. A., \& Boot, R. (2016). Participatory mapping to identify indigenous community use zones: Implications for conservation planning in southern Suriname. Journal of Nature Conservation, 29 69-78.

Ramirez-Gomez, S. O. I., Torres-Vitolas, C. A., Schreckenberg, K., Honzák, M., CruzGarcia, G. S., Willcock, S., et al. (2015). Analysis of ecosystem services provision in the Colombian Amazon using participatory research and mapping techniques. Ecosystem Services, 13, 93-107.

Reed, M. S. (2008). Stakeholder participation for environmental management: A literature review. Biological Conservation, 141, 2417-2431.

Reyers, B., Nel, J. L., O'Farrell, P. J., Sitas, N., \& Nel, D. C. (2015). Navigating complexity through knowledge coproduction: Mainstreaming ecosystem services into disaster risk reduction. Proceedings of the National Academy of Sciences, 112, $7362-7368$.

Sayer, J., Sunderland, T., Ghazoul, J., Pfund, J.-L., Sheil, D., Meijaard, E., et al. (2013). Ten principles for a landscape approach to reconciling agriculture, conservation, and other competing land uses. Proceedings of the National Academy of Sciences, $110,8349-8356$.

Schlager, E., \& Ostrom, E. (1992). Property-rights regimes and natural resources: A conceptual analysis. Land Economics, 68, 249-262.

Schreckenberg, K., Torres-Vitolas, C., Willcock, S., Shackleton, C., Harvey, C., \& ASSET team. (2014). Field Manual for community level data collection (ASSETS project report).

Sitas, N., Prozesky, H. E., Esler, K. J., \& Reyers, B. (2014). Opportunities and challenges for mainstreaming ecosystem services in development planning: Perspective 
from a landscape level. Landscape Ecology, 29, 1315-1331.

Stern, M. J., \& Baird, T. D. (2015). Trust ecology and the resilience of natural resource management institutions. Ecology and Society, 20(2), 14.

Sunderlin, W. D., Dewi, S., Puntodewo, A., Muller, D., Angelsen, A., \& Epprecht, M (2008). Why forests are important for global poverty alleviation: A spatial explanation. Ecology and Society, 13(2), 24.

Talen, E. (2000). Bottom-up GIS: A new tool for individual and group expression in participatory planning. Journal of the American Planning Association, 66(3), 279-294.

Terminski, B. (2014). Development-induced displacement and resettlement: Causes, consequences, and socio-legal context. Columbia University Press.

Termorshuizen, J. W., \& Opdam, P. (2009). Landscape services as a bridge between landscape ecology and sustainable development. Landscape Ecology, 24 1037-1052.
USGS. (2014). Shuttle radar topography mission (SRTM) [WWW Document]. URL https://lta.cr.usgs.gov/SRTM (Accessed 10 April 2014).

Vallés-Planells, M., Galiana, F., \& Van Eetvelde, V. (2014). A classification of landscape services to support local landscape planning. Ecol. Soc., 19(1), 44.

Villamor, G. B., Palomo, I., Santiago, C. A. L., Oteros-Rozas, E., \& Hill, J. (2014) Assessing stakeholders' perceptions and values towards social-ecological systems using participatory methods. Ecological Process, 3, 1-12.

Willemen, L., Drakou, E. G., Dunbar, M. B., Mayaux, P., \& Egoh, B. N. (2013). Safeguarding ecosystem services and livelihoods: Understanding the impact of conservation strategies on benefit flows to society. Ecosystem Services, 4, 95-103.

Wilson, M. A., \& Howarth, R. B. (2002). Discourse-based valuation of ecosystem services: Establishing fair outcomes through group deliberation. Ecological Economics, 41, 431-443. 